\title{
Impact of Syrian Forced Migration on Turkish Economy
}

Burçak Müge TUNAER-VURAL (https://orcid.org/0000-0002-4252-6276), Department of Economics, Dokuz Eylül University, Turkey; e-mail: muge.tunaer@deu.edu.tr

\section{Suriye'den Zorunlu Göçün Türkiye Ekonomisi Üzerindeki Etkileri}

\begin{abstract}
The purpose of this research is to analyse the economic impact of Syrian forced migration on Turkish economy. In order to assess the response of macroeconomic variables to the influx of Syrian refugees, we resort to Difference-in-Differences method. We compare Turkish provinces on the basis of three macroeconomic indicators -unemployment, inflation, and production- before and after forced migration occurred. We find that forced migration increased inflation and production significantly. In particular, housing prices rise considerably with Syrian migration. We estimate that $1 \%$ rise in migrant population raises both inflation and production by more than $1 \%$. We find statistically insignificant coefficients for unemployment. In addition, impact of forced migration displays regional differences. Regions with clustered industrial production are affected positively by the influx of Syrian migrants. Despite positive impact on industry clusters, findings indicate some deterioration of macroeconomic indicators of rural sectors.
\end{abstract}

Keywords : Forced Migration, Differences-in-differences.

JEL Classification Codes : J61, R23.

\section{Öz}

Bu çalışmanın amacı Suriye'den Türkiye'ye gerçekleşen zorunlu göçün Türkiye ekonomisinin makroekonomik değişkenleri üzerindeki etkilerini ölçümlemek ve değerlendirmektir. Zorunlu göç sonucu etkilenmesi beklenen temel makroekonomik göstergelerin zorunlu göç öncesinde ve zorunlu göç sonrasında değişimi, farkların farkı yöntemi kullanılarak araştırılmıştır. Zorunlu göçün hem enflasyonu hem de üretimi, istatistiksel olarak anlamlı şekilde, artırdığı gözlenmektedir. Özellikle, konut fiyatlarındaki artış kayda değer görülmektedir. Tahminlerimize göre, zorunlu göç eden nüfusta $\% 1$ 'lik bir artış, enflasyon ve üretimi \%1'den daha fazla artırmaktadır. İşsizlik değişkenine ilişkin katsayının istatistiki olarak anlamlı bir sonuç göstermediği görülmüştür. Ayrıca, elde edilen sonuçlar, zorunlu göçün etkilerinin bölgesel bazda farklılıklar gösterdiğini ortaya koymaktadır. Sanayi üretiminin ve ekonomik kümelenmenin yoğun olduğu bölgelerin göçten olumlu etkilendiği, buna karşın kırsal kesimde göç sonucunda makroekonomik göstergelerin kötüleştiği gözlenmektedir.

Anahtar Sözcükler $\quad$ : Zorunlu Göç, Farkların Farkı. 


\section{Introduction}

Break out of the civil conflict in Syria, in 2011, led to massive waves of forced migration from Northern Syria. Turkey has been recipient of the largest number of immigrants. According to official records, 2,8 million forced migrants entered Turkey in 2016. Turkish population of 78,7 million by 2016, surpassed 81 million the same year. Growing number of immigrants is expected to produce important social and economic consequences in the region. In the light of prevailing conflict and civil war conditions that has led to forced migration, one may expect aggravation of socio-economic impacts in the long run.

Forced migration produces positive and negative consequences for both forced displaced populations, and the host countries receiving them. Poverty, changes in human capital stock, and environmental effects are among the most important economic effects. Research on economic effects of forced migration started to regain academic interest in the beginning of 2000 s.

Understanding the economic consequences of forced migration would be essential for designing humanitarian assistance programs. A consistent estimate of costs and benefits would be informative about the effectiveness and efficiency of the implemented policies. There exists an extensive literature on economic effects of migration, though forced migration has distinct characteristics from voluntary migration. Many of the conclusions and policy recommendations drawn from studies on voluntary migration may not apply to forced migration situations. Considering more than 40 million people, all around the world, are forced to migrate today, economic impact of forced migration deserves academic interest.

Forced migration has economic consequences for both (1) forced migrants, and (2) hosting populations. The impact of forced migration on those who are forced to migrate depends on several factors including the characteristics of migrants, the nature of conflicts, and the degree of coordinated international engagement ${ }^{1}$. Main conclusion drawn from forced migration literature is that the forced migrants are exposed to increased poverty and constrained with lower levels of expenditure. Yet, it is considered as one of the main difficulties in most economic analyses of forced migration effects that whether the impact is the result of forced migration or the result of war and violence.

Forced migration shock may have both supply and demand side effects on the host economy. Supply side pressures are most commonly identified on host labour markets. Rise in population as a result of migrants' inflow, increases labour force participation, which in turn suppress wages. An influx of forced migrants may also have an impact on total demand products and services, and the effect on prices depends on opposing factors of supply and 
demand. Additionally, increase in number of forced migrants is expected to impose economic burden on the government in terms of public spending. Though, forced migration shock is not likely to have the same impact across all sectors of the economy. At the micro level, it is likely that there will be 'winners' and 'losers' of the host country groups.

The purpose of this research is to complement the emerging literature by analysing the economic impact of Syrian forced migration on Turkish economy. This paper extends previous research by focusing on three macroeconomic indicators, covering a larger time span of pre and post migration periods. We elaborate on the impact of Syrian migration on unemployment, inflation, and production. We distinguish between agricultural and industrial sectors of employment, as well as sub-categories of inflation, i.e. housing, and food. The analyses are conducted on regional (NUTS2) level. Even though previous research focus on South-eastern Anatolian regions as treatment area, we identified Western regions that are exposed to high intensity of forced migration and investigated the impact of forced migration on those area. The remainder of the paper is organised as follows. Section 1 describes the theoretical framework of this research. Possible effects of forced migration on economic variables are to be investigated based on relevant literature under this section. Section 2 introduces the empirical methodology to be employed to quantify the economic impact of forced migration. Section 3 presents and discusses the empirical findings. The final section makes concluding remarks and some policy proposals.

\section{Economic Impact of Forced Migration}

This section aims to identify theoretical linkages between forced migration inflows and the related changes in economic variables in host countries. Zetter (2012: 39) suggests an analytical approach, based on assessing economic impacts on host populations, on both macro and micro levels. Indicators for income, labour market, assets, and savings are identified as microeconomic parameters, while housing markets, prices, capital formation, and GDP indicators are categorised under macroeconomic parameters (see Table 1).

Table: 1

Key Parameters and Indicators

\begin{tabular}{|c|c|}
\hline Mikroeconomic Parameters & Macroeconomic Parameters \\
\hline $\begin{array}{l}\text { Income } \\
\text { Income / Disposable income } \\
\text { Consumption levels }\end{array}$ & $\begin{array}{l}\text { Housing Markets } \\
\text { Housing supply / demand } \\
\text { Costs } \\
\text { Rental markets }\end{array}$ \\
\hline $\begin{array}{l}\text { Labour Markets } \\
\text { Wages } \\
\text { Employment } \\
\text { Type of job } \\
\text { Labour force participation } \\
\text { Hours worked }\end{array}$ & $\begin{array}{l}\text { Prices } \\
\text { Goods and services }\end{array}$ \\
\hline $\begin{array}{l}\text { Assets } \\
\text { Livestock }\end{array}$ & $\begin{array}{l}\text { Capital Stock } \\
\text { Construction / Infrastructure }\end{array}$ \\
\hline Savings & $\begin{array}{l}\text { GDP } \\
\text { Increase / Decrease }\end{array}$ \\
\hline
\end{tabular}

Source: Zetter (2012: 39).

The methodology to assess the impact of forced migration influx on host populations is typically based on before and after migration shock comparison of the selected variables. 
Although, it is important to note that the impact of forced migration is likely to vary among hosting populations (Whitaker, 2002: 354-356). Demographic and socio-economic factors, such as age, gender, income groups, are supposed to alter the sensitivity of these different groups to the forced migration shocks.

Studies assessing the microeconomic impact of forced migration, in general, use household surveys on income and labour market parameters. Although, variables such as employment, consumption, and income are generally considered to be macro variables, literature is merely based on household level data and micro analysis of these variables. Analysis of housing market, prices (general and sectoral), capital stock, and GDP variables, on the other hand, are based on observation of macroeconomic data sets.

Maystadt and Verwimp (2014: 20-22) found that in Kagera region of Tanzania, with the influx of forced migration from Burundi and Rwanda, rising household consumption increased the economic welfare. Their results further confirm that the impact is highly differentiated among refugee hosting groups. While agricultural labour suffers from fiercer competition and lower wages, non-agricultural sector and skilled labour tends to improve their welfare as a result of increased demand for skilled labour and increased wages in nonagricultural sector. Similarly, Calderon and Ibanez (2009: 12-24) demonstrated that forced migration produced uneven labour market outcomes in Colombia. Their findings suggest an expansion of the informal sector, creating large negative impact on wages and employment. The impact seems to be significantly higher for lower skilled and female workers. Braun and Mahmoud (2014: 83-88) found that post World War II influx of German expellees from Eastern Europe reduced employment opportunities for German natives. A ten-percentage point increase in the share of German expellees reduced the employment of German natives by more than two and a half percentage points. The empirical evidence has been inconclusive and ambiguous regarding the economic effects of forced migration among hosting groups. While forced migration raised some groups' welfare, it had negative impact on other groups' welfare by decreasing job opportunities and exerting downward pressure in wages. Impact of forced migration on labour markets basically depends on how closely hosting groups are substituted by forced migrants.

Limited number of research concerning the impact of Syrian migration on Turkish economy also reveals conflicting empirical results. Most of these academic papers focus on the labour market outcomes of Syrian refugee influx in Turkey. Del Carpio and Wagner (2015: 12-30), used micro level data and employed an econometric identification based on IV strategy to estimate the impact of Syrian refugee influx on the Turkish labour market. They found that refugees largely displaced natives from the informal sector. At the same time, they reported increase in formal employment for the Turkish. These findings are compatible with what Ceritoğlu et al. (2017: 12-19) found. Employing a different econometric approach, they reported similar results indicating refugee-induced changes in Turkish employment composition. In this new composition, refugees substitute native workers in the informal sector, while slightly increasing formal employment of natives. On the other hand, these two papers report different outcomes in terms of wage effects. While Del Carpio and Wagner (2015: 23-25) reported statistically significant declines in natives' 
wages, Ceritoğlu et al. (2017: 4) found no wage-effects. Apart from these findings, Akgündüz et al. (2015: 13-15) argued that Syrian forced migration, in years 2012 and 2013, did not have any significant impact on Turkish labour market at all. Yet, Bahçekapılı and Çetin (2015: 7-13) found a considerable increase in unemployment in Malatya, Elazı̆̆ Bingöl, Tunceli, Kilis, Konya, Gaziantep, and Adiyaman caused by the fact that Syrian refugees moving to these cities provided cheap labour, resulting an increased labour supply.

To the best of author's knowledge, there exist two more researches providing complementary effort in understanding the impact of Syrian refugees on Turkish economy. First, Balkan and Tümen (2016: 14-16) explained falling consumer prices in hosting regions by labour cost advantages gained in immigrant intensive sectors due to lower wages paid to Syrian refugees. Second study, focusing on housing market effects, found support for residential segregation story, which suggests that refugee inflow has increased the demand for better and safer neighbourhoods especially among natives (Balkan et al., 2018: 17).

\section{Data and Methodology}

The data used in this research come from various sources. Provincial breakdown of the number of Syrian forced migrants in Turkey is extracted from the reports of United Nations High Commissioner for Refugees (UNHCR). Directorate General of Migration Management (DGMM) also issues Turkish Migration Report annually. The report also provides the distribution of Syrian Refugees in the scope of temporary protection by province. Both the UNHCR and DGMM data are in conformity with each other. The number of refugees includes all registered Syrians, both in camps and those residing in urban areas, under temporary protection. Unemployment, inflation, and GDP data on regional (NUTS 2) basis are obtained from TUIK Regional Accounts database. Inflation data refers to the annual rate of change in the consumer price index (base year 2003). We also employed two separate subcategories of consumer price index; food and housing, since these subcategories characterise the most likely sectors where the increased population pressure would put a strain on sectoral demand. The dataset covers the period 2006-2017. First group of Syrian refugees entered Turkey in April 2011. Thus, the period of 2006-2011 is identified as premigration period, and the period of 2012-2017 as post-migration period. Table 2 provides the summary statistics for inflation, employment, and GDP for treatment and alternative control regions over the pre-migration and post-migration periods.

Empirical investigation of the economic impact of forced migration requires a detailed evaluation based on spatial and time dimensions. In order to assess the response of macroeconomic variables to the influx of Syrian refugees, we resort to Difference-inDifferences method. Accordingly, we determined the regions receiving highest influx of Syrian refugees, and the regions either not receiving or receiving a minor amount of Syrian forced migration. Since we consider that the spread of migrants to different locations does not follow a certain pattern to associate with locational characteristics, we assume a random selection of each location by migrants. Then the regions (NUTS II) with high and low forced migrants intensity are compared based on their macro indicators of unemployment, inflation and growth rates for pre and post migration periods. We employed two alternative control 
regions in order to check robustness of our results. The first alternative control unit is constructed by focusing on Eastern Anatolian regions. Following Ceritoğlu et al. (2017: 11), we included 4 Eastern Anatolian regions since they resemble most social/demographic characteristics of the treatment regions. We also constructed a synthetic control unit to employ as a second alternative to our original control unit. We held treatment regression fixed and performed regression analysis separately for each of the alternative control units. In case of robustness, we do not expect results to be significantly different.

\section{Table: 2}

Main Indicators Before and After Syrian Migration

\begin{tabular}{|c|c|c|c|c|c|c|c|c|}
\hline & \multicolumn{4}{|c|}{ Pre-Migration (2006-2011) } & \multicolumn{4}{|c|}{ Post-Migration (2012-2017) } \\
\hline & Treatment & Control & $\begin{array}{c}\text { Alternative } \\
\text { Control }\end{array}$ & $\begin{array}{c}\text { Synthetic } \\
\text { Control }\end{array}$ & Treatment & Control & $\begin{array}{c}\text { Alternative } \\
\text { Control }\end{array}$ & $\begin{array}{c}\text { Synthetic } \\
\text { Control }\end{array}$ \\
\hline Unemployment (\%) & 12,96 & 8,58 & 10,78 & 11,65 & 11,74 & 6,86 & 7,49 & 11,22 \\
\hline Inflation (\%) & 8,20 & 7,67 & 8,52 & 8,33 & 7,64 & 6,65 & 7,23 & 7,05 \\
\hline Inflation: Food (\%) & 8,55 & 7,93 & 9,18 & 8,12 & 10,40 & 10,17 & 9,72 & 9,11 \\
\hline Inflation: Housing (\%) & 7,39 & 7,03 & 7,79 & 7,55 & 8,14 & 7,71 & 7,70 & 7,84 \\
\hline Production (per capita / TL) & 14896 & 11268 & 8316 & 14222 & 22698 & 18453 & 13876 & 20340 \\
\hline
\end{tabular}

Note: The treatment area includes 13 NUTS II provinces of Turkey that are defined as high forced migration intensity regions. Control area includes the rest of Turkey classified as low forced migration intensity regions. Alternative Control area consists of 4 Eastern Anatolian regions (TRA1-Erzurum, TRA2-A ğrl, TRB1-Malatya, TRB2-Van). Synthetic Control Unit consists of weighted average of provinces chosen from the donor pool (rest of Turkey).

Low and high intensity regions are determined according to statistics provided by Turkish Ministry of Interior Directorate General of Migration Management. As of 2016, 26 temporary accommodation centres are established in 10 provinces. While 260.163 Syrian migrants are in these temporary accommodation centres, there are 2.580.933 Syrians recorded biometrically that are out of these accommodation centres (see Appendix 1). In addition, according to official records, all 81 provinces are affected by the Syrian migration, more or less. We defined NUTS II regions with high forced migration intensity in accordance with the provision of temporary accommodation centres. These regions are Hatay (TR63), Malatya (TRB1), Gaziantep (TRC1), Şanlıurfa (TRC2), Mardin (TRC3). Yet, considering that more than $85 \%$ of Syrian migrants are living out of the temporary accommodation centres, regions with high Syrian population but without temporary accommodation centres are also classified as high forced migration intensity regions. These regions are İstanbul (TR10), İzmir (TR31), Bursa (TR41), Kocaeli (TR42), Ankara (TR51), Konya (TR52), Adana (TR62) and Kayseri (TR72) (see Appendix 2). Rest of the NUTS II regions of Turkey are aggregated and considered as low forced migration intensity regions (TR).

In order to estimate the impact of forced migration inflow, we compare three macro indicators for Turkish economy before and after forced migration occurred. Using difference-in-difference estimator, the comparison is formulated as follows:

$$
\begin{aligned}
& \left(U_{p o s t, R}-U_{p r e, R}\right)-\left(U_{\text {post }, T R}-U_{p r e, T R}\right) \\
& \left(\pi_{p o s t, R}-\pi_{p r e, R}\right)-\left(\pi_{p o s t, T R}-\pi_{p r e, T R}\right)
\end{aligned}
$$




$$
\left(G D P_{\text {post }, R}-G D P_{\text {pre }, R}\right)-\left(G D P_{\text {post }, T R}-G D P_{\text {pre }, T R}\right)
$$

First equation compares pre and post forced migration unemployment rates $(U)$ in high forced migration intensity regions, and the rest of Turkey. Subscript $R$ is assigned to indicate high forced migration intensity regions, while $T R$ denotes rest of Turkish regions with low forced migration intensity. Second equation compares pre and post migration inflation rates between high forced migration intensity regions and the low forced migration intensity regions, while third equation accounts for the comparison of Gross Domestic Product.

'Parallel trends' assumption that the difference-in-difference method rests on implies that without intervention, outcomes of the treated and control groups would have followed parallel trajectories. This proposition, however, remains to be challenging when one considers the dual structure of Turkish economy, i.e. economic differences between eastern and western parts of Turkey. Even if the refugee inflow is sudden and randomly distributed among geographical locations, high-intensity regions may be capable of producing different outcomes compared to low-intensity regions due to unobserved time-varying confounders (Xu, 2017: 62). In order to deal with this issue, we construct an alternative synthetic control unit as originally proposed by Abadie et al. (2010: 497-99). As suggested by Abadie et al. (2010: 497), we aggregated the treated units (high-intensity regions) into a single treated unit (region). Of $\mathrm{J}+1$ units (regions), the first unit (indexed by $\mathrm{j}$ ) $\mathrm{j}=1$ is the treated unit, and units $\mathrm{j}=2$ to $\mathrm{j}=\mathrm{J}+1$ are referred to as the 'donor pool'. The synthetic control unit is identified as a weighted average of the units in the donor pool. That is, $(\mathrm{J}+1)$ vector of non-negative weights $\mathrm{W}=\left(w_{2}, \ldots w_{j+1}\right)^{\prime}$, and $w_{2}+\cdots+w_{j+1}=1$. Let $Y_{1}$ represent $(\mathrm{kx} 1)$ pre-treatment vector of variables for high intensity regions, and $Y_{0}$ be the $(\mathrm{kxj})$ matrix of variables in the donor pool. Then, $Y_{1}-Y_{0} W$ gives the difference between pre-treatment characteristics of the high intensity regions and the synthetic control unit. We choose $W^{*}$ so as to minimise this difference. Synthetic control unit is computed using readily available scripts that have written for STATA.

In order to assess the impact of Syrian migration on macroeconomic indicators we estimate the following regressions:

$$
\begin{array}{lll}
U_{i t}=\alpha+\beta I_{i t}+T_{t}+R_{i}+e_{i t} & i=1, \ldots, 26 & t=1, \ldots, 12 \\
\pi_{i t}=\alpha+\beta I_{i t}+T_{t}+R_{i}+e_{i t} & i=1, \ldots, 26 & t=1, \ldots, 12 \\
G D P_{i t}=\alpha+\beta I_{i t}+T_{t}+R_{i}+e_{i t} & i=1, \ldots, 26 & t=1, \ldots, 12
\end{array}
$$

Here, $I_{i t}$ is the treatment variable that captures the effect of Syrian migrants. The impact of the Syrian forced migration on macroeconomic indicators, unemployment, inflation, and GDP is evaluated by the OLS estimator $\beta$. We employed three alternative treatment variables to measure the impact of Syrian migration influx: the number of Syrian forced migrants in the region, a binary indicator that is unity if the region is a high forced migration intensity region, and a continuous treatment variable indicating the ratio of Syrian 
refugees to population in the region. Economic outcome of interest in the sixth equation is described as a function of natural logarithm of GDP. The interpretation of $\beta$ in this case is the percentage change in the economic outcome (GDP) for being impacted by Syrian forced migration. $T_{t}$ and $R_{i}$ are fixed effects for years and regions, respectively. In order to account for sectoral effects of forced migration on employment, fourth regression is estimated separately for agricultural and industrial sectors.

Since the forced migrants may tend to immigrate to regions with booming economies, the assumption of the conditional exogeneity of migration variable may fail. Thus, potential problems of endogeneity may arise, rendering the cross-sectional estimates potentially inconsistent, when making comparisons between heterogeneous groups, such as the regions of Turkish economy. However, Syrian migration flows were initiated by a forced movement across the border, and have been mainly towards the border cities in the Southeastern region of Turkey. Therefore, selection problem should not occur in our case due to this random characteristic of migration movement. Yet, the OLS estimators of the difference in difference set-up may suffer from important serial correlation problems (Bertrand et al., 2004: 273). In order to correct the problem of serial correlation, we applied bootstrap method of Hounkannounon (2011: 3-8). Alternatively, we employed another estimation technique to address the same problem. We removed the time series dimension of the dataset by aggregating the data into two periods: pre-migration period (2006-2011), and post-migration period (2012-2017).

\section{Empirical Findings}

The effects of Syrian forced migration on Turkish macro-economy are assessed on regional basis. The OLS estimates of the regressions (4), (5), and (6) measure the impact of forced migration on unemployment, inflation, and GDP respectively. Coefficients and the bootstrapped t-statistics are presented in Table 3.

The estimates of the impact of Syrian forced migrants on general employment are insignificant, which corroborates the findings of Akgündüz et al. (2015: 14-16). However, the estimated effect becomes significant once we account for sectoral differences. Our results suggest that Syrian forced migration inflow increases agricultural unemployment, while the impact on industrial sector appears to be the opposite. Both coefficients are statistically significant. One explanation to this issue may be that the Syrian labour participation to Turkish agricultural economy maybe exerting a substitution effect. Syrian migrants inflow to the agricultural sector provided cheap labour as a result of increased labour supply. Close competition among Syrian migrants and Turkish labour is, then, supposed to push down the labour costs in agricultural sector. Increased supply of lowskilled labour, on the other hand may have served to the advantage of the labour intensive industrial sector in Turkey, contributing positively to employment in industrial sector (ORSAM-TESEV, 2015: 18). In addition, the significant difference between agricultural and industrial sectors in employment terms may also give rise to suspects of some selection bias. Employment opportunities associated with industrial districts may have attracted more migrants, giving rise to different outcomes in terms of unemployment in between urban and 
rural regions. Taking long time span covering post-migration period after the initial migration movement into consideration, we may expect to observe self-selection bias concerning the migration towards industrial cities, i.e. İstanbul. Thus, the results of this natural experiment should be interpreted with caution.

Table: 3

Impact of Forced Migration on Macroeconomic Indicators

\begin{tabular}{|c|c|c|c|c|c|c|c|}
\hline & Unemployment & $\begin{array}{l}\text { Unemployment } \\
\text { Agriculture }\end{array}$ & $\begin{array}{l}\text { Unemployment } \\
\text { Industry }\end{array}$ & Inflation & $\begin{array}{l}\text { Inflation } \\
\text { Food }\end{array}$ & $\begin{array}{l}\text { Inflation } \\
\text { Housing }\end{array}$ & Production \\
\hline $\begin{array}{l}\text { Independent Variable: } \\
\text { Number of Syrian forced migrants }\end{array}$ & $\begin{array}{c}0,008 \\
(0,311)\end{array}$ & $\begin{array}{l}0,022 * * \\
(0,612)\end{array}$ & $\begin{array}{c}-0,018 * * \\
(-0,826)\end{array}$ & $\begin{array}{c}0,012 * * \\
(1,138)\end{array}$ & $\begin{array}{c}0,018 \\
(0,842)\end{array}$ & $\begin{array}{l}0,011 * * \\
(1,243)\end{array}$ & $\begin{array}{l}0,015 * * \\
(1.113)\end{array}$ \\
\hline Year Effects & YES & YES & YES & YES & YES & YES & YES \\
\hline Region Effects & YES & YES & YES & YES & YES & YES & YES \\
\hline Rsqr & 0,34 & 0,32 & 0,44 & 0,40 & 0,35 & 0,36 & 0,34 \\
\hline Number of Obs. & 312 & 312 & 312 & 312 & 312 & 312 & 312 \\
\hline $\begin{array}{l}\text { Independent Variable: } \\
\text { Exposure to Syrian forced migrants }\end{array}$ & $\begin{array}{c}0,009 \\
(0,423)\end{array}$ & $\begin{array}{l}0,019 * \\
(0,543)\end{array}$ & $\begin{array}{c}-0,021 * * \\
(-0,632)\end{array}$ & $\begin{array}{c}0,014 * * \\
(1,370)\end{array}$ & $\begin{array}{c}0,014 \\
(0,452)\end{array}$ & $\begin{array}{l}0,012^{* * *} \\
(1,524)\end{array}$ & $\begin{array}{l}0,012 * \\
(2,014)\end{array}$ \\
\hline Year Effects & YES & YES & YES & YES & YES & YES & YES \\
\hline Region Effects & YES & YES & YES & YES & YES & YES & YES \\
\hline Rsqr & 0.32 & 0,32 & 0,34 & 0,40 & 0,38 & 0.34 & 0,38 \\
\hline Number of Obs. & 312 & 312 & 312 & 312 & 312 & 312 & 312 \\
\hline $\begin{array}{l}\text { Independent Variable: } \\
\text { Ratio of Syrian Refugees to population }\end{array}$ & $\begin{array}{c}0,01 \\
(0,243)\end{array}$ & $\begin{array}{c}0,030 * * \\
(0,478)\end{array}$ & $\begin{array}{c}-0,026^{* *} \\
(-0,554)\end{array}$ & $\begin{array}{l}0,012 * \\
(0,911)\end{array}$ & $\begin{array}{l}0,015^{*} \\
(0,675)\end{array}$ & $\begin{array}{c}0,014 * * \\
(0.898)\end{array}$ & $\begin{array}{c}0,014 * * \\
(1,102)\end{array}$ \\
\hline Year Effects & YES & YES & YES & YES & YES & YES & YES \\
\hline Region Effects & YES & YES & YES & YES & YES & YES & YES \\
\hline Rsqr & 0,40 & 0,38 & 0,40 & 0,36 & 0,34 & 0,34 & 0,32 \\
\hline Number of Obs. & 312 & 312 & 312 & 312 & 312 & 312 & 312 \\
\hline
\end{tabular}

Coefficients of inflation and housing inflation are both positive and statistically significant. As suggested by Ruiz and Vargas-Silva (2013: 780-82), the reason for this effect may be the increase in total population of the region has led to rise in total demand for products and services, in particular for necessities such as food and housing prices. Findings of a previous study by Akgündüz et al. (2015: 11-13) confirm that the food and housing prices in Turkey have risen with the Syrian forced migration. Significance of the positive coefficient of consumer price index based inflation may also be attributed to the high share of household necessities, such as housing, and energy consumption in consumer price index. In contrast, our results indicate no significant rise in food inflation, except for the regression with an independent variable of ratio of Syrian refugees to population. This finding differs from that of Akgündüz et al. (2015: 11). Longer time series dimension of the data allows us to account for lagging impact, and one possible explanation for this may be falling cost of production in agricultural sector, as mentioned before.

Production is another indicator that we considered in our empirical analysis. Positive and statistically significant coefficient of production variable (GDP) shows that the Syrian forced migration has caused an increase in activity. Significant inflow of Syrian migrants has imposed both supply and demand shifts on Turkish economy. We found that a $1 \%$ increase in population is associated with a rise in production by nearly $1,2 \%$.

We perform robustness checks to test the reliability of our baseline results. First, we replace our control regions with two alternative control areas. The first alternative control area consists of 4 Eastern Anatolian regions (TRA1-Erzurum, TRA2-Ağr1, TRB1-Malatya, TRB2-Van. This is the same control region employed in the study by Ceritoğlu et al. (2017: 
11). The second control area is a synthetic control unit constructed by using the methodology suggested by Abadie et al. (2010: 497-99). Second, we include region specific time trends to probe the robustness of our difference in differences identification. Results of the robustness check are reported in the Table 4.

\section{Table: 4}

\section{Robustness Exercise}

\begin{tabular}{|c|c|c|c|c|c|c|c|}
\hline & Unemployment & $\begin{array}{c}\text { Unemployment } \\
\text { Agriculture }\end{array}$ & $\begin{array}{c}\text { Unemployment } \\
\text { Industry }\end{array}$ & Inflation & $\begin{array}{c}\text { Inflation } \\
\text { Food }\end{array}$ & $\begin{array}{l}\text { Inflation } \\
\text { Housing }\end{array}$ & Production \\
\hline \multicolumn{8}{|c|}{ Independent Variable: Number of Syrian forced migrants } \\
\hline Original Control & $\begin{array}{c}0,005 \\
(0,011)\end{array}$ & $\begin{array}{c}0,018 * * \\
(0,495)\end{array}$ & $\begin{array}{l}-0,020 * * \\
(-0,592)\end{array}$ & $\begin{array}{l}0,009 * \\
(0,883)\end{array}$ & $\begin{array}{c}0,016 \\
(0,677)\end{array}$ & $\begin{array}{c}0,011 * * \\
(1,631)\end{array}$ & $\begin{array}{l}0,011 * * \\
(1,302)\end{array}$ \\
\hline Alternative Control & $\begin{array}{c}0,004 \\
(0,513) \\
\end{array}$ & $\begin{array}{c}0,018 * * \\
(0,652)\end{array}$ & $\begin{array}{l}-0,014^{*} \\
(-0,833)\end{array}$ & $\begin{array}{l}0,008 * \\
(0,638)\end{array}$ & $\begin{array}{l}0,018^{*} \\
(0,841) \\
\end{array}$ & $\begin{array}{c}0,009 * * \\
(1,243) \\
\end{array}$ & $\begin{array}{c}0,008 * * \\
(1,113) \\
\end{array}$ \\
\hline Synthetic Control & $\begin{array}{c}0,005 \\
(0,113)\end{array}$ & $\begin{array}{c}0,012 * * \\
(0,471)\end{array}$ & $\begin{array}{c}-0,016^{* * *} \\
(-0,398)\end{array}$ & $\begin{array}{l}0,004 * \\
(0,588)\end{array}$ & $\begin{array}{l}0,016^{*} \\
(0,492)\end{array}$ & $\begin{array}{l}0,010 * \\
(0,893)\end{array}$ & $\begin{array}{c}0,011 * * \\
(0,796)\end{array}$ \\
\hline Year Effects & YES & YES & YES & YES & YES & YES & YES \\
\hline Region Effects & YES & YES & YES & YES & YES & YES & YES \\
\hline Region Time Trends & YES & YES & YES & YES & YES & YES & YES \\
\hline \multicolumn{8}{|c|}{ Independent Variable: Exposure to Syrian forced migrants } \\
\hline Original Control & $\begin{array}{l}0,008 * \\
(0,310)\end{array}$ & $\begin{array}{l}0,015^{*} \\
(0,403)\end{array}$ & $\begin{array}{c}-0,018 * * \\
(-0,942)\end{array}$ & $\begin{array}{c}0,013 * * \\
(1,010)\end{array}$ & $\begin{array}{c}0,011 \\
(0,051)\end{array}$ & $\begin{array}{c}0,010 * * \\
(0,041)\end{array}$ & $\begin{array}{c}0,011 * * \\
(1,002)\end{array}$ \\
\hline Alternative Control & $\begin{array}{l}0,006^{*} \\
(0,032)\end{array}$ & $\begin{array}{l}0,013 * * \\
(0,291)\end{array}$ & $\begin{array}{c}-0,017 * * \\
(0,349)\end{array}$ & $\begin{array}{c}0,011 \\
(0,457)\end{array}$ & $\begin{array}{l}0,009^{*} \\
0,294)\end{array}$ & $\begin{array}{c}0,008 * * \\
(0,743)\end{array}$ & $\begin{array}{c}0,010 * * \\
(1,012) \\
\end{array}$ \\
\hline Synthetic Control & $\begin{array}{c}0,008 \\
(0,098)\end{array}$ & $\begin{array}{c}0,012 * * \\
(0,893)\end{array}$ & $\begin{array}{c}-0,014 * * \\
(-0,592)\end{array}$ & $\begin{array}{l}0,011 * \\
(1,014)\end{array}$ & $\begin{array}{c}0,011 \\
(0,232)\end{array}$ & $\begin{array}{l}0,006 * \\
(1,231)\end{array}$ & $\begin{array}{l}0,009 * \\
(0,497)\end{array}$ \\
\hline Year Effects & YES & YES & YES & YES & YES & YES & YES \\
\hline Region Effects & YES & YES & YES & YES & YES & YES & YES \\
\hline Region Time Trends & YES & YES & YES & YES & YES & YES & YES \\
\hline \multicolumn{8}{|c|}{ Independent Variable: Ratio of Syrian Refugees to population } \\
\hline Original Control & $\begin{array}{l}0,009 * \\
(0,008)\end{array}$ & $\begin{array}{c}0,022 * * \\
(0,089)\end{array}$ & $\begin{array}{c}-0,019 * * \\
(-0,931)\end{array}$ & $\begin{array}{l}0,012 * \\
(0,685)\end{array}$ & $\begin{array}{l}0,012 * \\
(0,702)\end{array}$ & $\begin{array}{c}0,013 * * \\
(1,028)\end{array}$ & $\begin{array}{c}0,011 * * \\
(0,545)\end{array}$ \\
\hline Alternative Control & $\begin{array}{l}0,006 * \\
(0,234)\end{array}$ & $\begin{array}{c}0,018 * * \\
(0,491)\end{array}$ & $\begin{array}{c}-0,018^{*} \\
(0,089)\end{array}$ & $\begin{array}{l}0,011^{*} \\
(0,554)\end{array}$ & $\begin{array}{c}0,009 * * \\
(0,470)\end{array}$ & $\begin{array}{c}0,012 * * \\
(0,989)\end{array}$ & $\begin{array}{c}0,010 * * \\
(1,198)\end{array}$ \\
\hline Synthetic Control & $\begin{array}{c}0,004 \\
(0,108)\end{array}$ & $\begin{array}{c}0,021 * * \\
(0,384)\end{array}$ & $\begin{array}{c}-0,019 * * \\
(0,198)\end{array}$ & $\begin{array}{c}0,009 * * \\
(0,808)\end{array}$ & $\begin{array}{l}0,013 * \\
(0,663)\end{array}$ & $\begin{array}{c}0,011 * * \\
(0,890)\end{array}$ & $\begin{array}{c}0,012 * * \\
(0,916)\end{array}$ \\
\hline Year Effects & YES & YES & YES & YES & YES & YES & YES \\
\hline Region Effects & YES & YES & YES & YES & YES & YES & YES \\
\hline Region Time Trends & YES & YES & YES & YES & YES & YES & YES \\
\hline
\end{tabular}

When we include region specific time trends, all three regressors yield slightly smaller coefficients, with unchanged statistical significance. This suggests that our results are robust, and eliminates the possibility that our treatment and control regions have already been on completely different trajectories in terms of these indicators. Our results remain robust against inclusion of alternative control units as well. We also find that the coefficient of food inflation becomes significant with the employment of alternative control units. Results show some minor differences for the rest of other regressions. Yet, robustness checks verify the general validity of the regression analysis.

Second stage of our empirical analysis compares high forced migration intensity regions to low forced intensity regions for the pre and post migration periods in terms of key macroeconomic indicators, i.e. production, employment, and inflation (see Appendix 3). To address the problem of serial correlation, we removed time series dimension of the dataset by aggregating the data into two periods, i.e. pre and post forced migration. Last column of the Appendix 3 shows the coefficients obtained from the analysis. Each coefficient represents the difference from pre-forced migration to post-forced migration period between low forced migration intensity regions and high forced migration intensity regions for each 
macroeconomic indicator. Positive (negative) sign of the coefficient shows that the macroeconomic indicator of the high forced migration intensity region is positively (negatively) diverging from the low forced migration intensity region.

Findings indicate that the increase in population of forced migrants in a region has raised total demand for goods and services, leading to inflationary pressure. Results for all regions of high forced migration intensity, except Kayseri and Malatya, show an inflationary response to the shock of forced migration. Şanlıurfa region appears to be hit by the highest impact of inflation. Forced migrants from Syria are expected to increase the demand for necessities faster than the rest of the other goods and services. However, consumption basket used in calculation of inflation is heterogeneous, leaving most of the goods and services unrelated to the consumption of forced migrants. Thus, taking heterogeneous characteristic of consumption basket into consideration, we estimated the impact of forced migration on food and housing inflation. We found significant impact on housing prices. Impact on food inflation, on the other hand, found to be insignificant in particular for the rural regions. This may be explained by lower cost of production due to cheap labour provided by Syrian migrants. This result is consistent with the findings of Del Carpio and Wagner (2015: 24), and Esen and Oğuş Binatlı (2017: 6-10). They find that Syrian refugees employed in informal labour market for lower wages are displacing Turkish workers. In fact, we observe fast rise in unemployment in regions of Hatay, Şanliurfa, and Mardin. These regions are known to be rural areas, mostly dependent on agricultural production. This may be interpreted as the substitution effect of Syrian cheap labour for more expensive Turkish labour in agricultural sector.

Finally, the results show positive impact on employment for the regions of İstanbul, Bursa, Kocaeli, Gaziantep, Malatya, and Konya. Employment growth has been achieved in these regions, where existing industrial clusters produce capacity to absorb increased participation to labour with the Syrian influx. Decreasing rates of unemployment and the rise in production, together with the inflationary pressure may be interpreted as the evidence for cost push inflation.

\section{Concluding Remarks}

Syrian armed conflict erupted in 2011, forced over 12 million Syrians to move out of Syria, sparking one of the largest refugee movements in modern history. There were more than 3 million Syrian forced migrants estimated to enter Turkey, as reported by the official statistics. This massive inflow of Syrian forced migration-imposed variety of multifaceted impact on Turkish economy. This paper investigates the economic effects of Syrian forced migration to Turkey in a macro perspective. Syrian forced migrants, becoming actors of Turkish economy, impacted on both supply and demand forces.

Using data on inflation and production, regressions yielded statistically significant results indicating some important impact on Turkish economy by the inflow of Syrian forced migrants. Impact of Syrian migrants on unemployment is somewhat complex. Even though, impact of migration turns out to be insignificant on general unemployment, sectoral 
decomposition reveals positive effect on agricultural employment. An explanation for this situation might be the falling cost of labour due to increased labour participation with the Syrian influx. Increased population, on the other hand, increased demand for necessities, such as food and housing. Rising prices in food and housing, thus, maybe interpreted as the sign of demand pulled inflation.

Impact of forced migration displays regional differences. Regions with clustered industrial production are affected positively by the influx of Syrian migrants. Despite positive impact on industry clusters, findings indicate some deterioration of macroeconomic indicators of rural sectors. Rate of employment and production increases with the intensity of Syrian forced migrants in industrial districts, such as İstanbul, Bursa, Kocaeli, Gaziantep, and Konya. In contrast, presence of Syrian forced migrants in rural regions -Hatay, Diyarbakır, and Şanlıurfa- is associated with lower rate of production and higher rate of unemployment. Considering the dual structure of Turkish economy, forced migration influx generates opposing effects on agricultural and industrial sectors. Findings indicate deepening dual economic structure due to diverging impacts of forced migration on industrial and agricultural sectors. Therefore, policy makers have to account for regional differences, and design regional policies accordingly, in order to support rural regions against forced migration shocks.

\section{References}

Abadie, A. \& A. Diamond \& J. Heinmueller (2010), "Synthetic Control Methods for Comparative Case Studies: Estimating the Effect of California's Tobacco Control Program", Journal of the American Statistical Association, 105(490), 493-505.

Akgündüz, Y.E. \& M. Van den Berg \& M. Hassink (2015), "The Impact of Refugee Crises on Host Labor Markets: The Case of the Syrian Refugee Crises in Turkey", Discussion Paper Series, No: 8841, IZA.

Bahçekap1l1, C. \& B. Çetin (2015), "The Impacts of Forced Migration on Regional Economies: The Case of Syrian Refugees in Turkey", International Business Research, 8 (9), 1-15.

Balkan, B. \& E.Ö. Tok \& H. Torun \& S. Tümen (2018), "Immigration, Housing Rents, and Residential Segregation: Evidence from Syrian Refugees in Turkey”, Discussion Paper Series, No. 11611, IZA.

Balkan, B. \& S. Tümen (2016), "Immigration and Prices: Quasi-Experimental Evidence from Syrian Refugees in Turkey", Journal of Population Economics, 29(3), 657-686.

Bauer, T.K. \& S. Braun \& M. Kvasnicka (2011), "The Economic Migration of Forced Migrants: Evidence for Post-War Germany", Discussion Paper, No. 5855, IZA.

Bertrand, M. \& E. Duflo \& S. Mullainathan (2004), "How Much Should We Trust Differences-inDifferences Estimates?", The Quarterly Journal of Economics, 119(1), 249-275.

Bozzoli, C. \& T. Brück (2010), "Child Morbidity and Camp Decongestion in Post-War Uganda”, Research Working Paper, No. 24, MICROCON.

Braun, S. \& T.O. Mahmoud (2014), "The Employment Effects of Immigration: Evidence from the Mass Arrival of German Expellees in Post-War Germany", The Journal of Economic History, 74(1), 69-108. 
Calderon, V.V. \& A.M. Ibanez (2009), "Labour Market Effects of Migration - Related Supply Shocks: Evidence from Internally Displaced Populations in Colombia”, Research Working Paper, No. 14, MICROCON.

Ceritoğlu, E. \& H.B.G. Yüncüler \& H. Torun \& S. Tümen (2017), “The Impact of Syrian Refugees on Natives' Labor Market Outcomes in Turkey: Evidence from a Quasi-Experimental Design", IZA Journal of Labor Policy, 6(5), 1-28.

Del Carpio, X.V. \& M.C. Wagner (2015), "The Impact of Syrian Refugees on Turkish Labor Market”, World Bank Policy Research Working Paper, No. 7402, Washington DC, United States.

Esen, O. \& A. Oğuş-Binatlı (2017), "The Impact of Syrian Refugees on Turkish Economy: Regional Labour Market Effects”, Social Sciences, 6(4), 1-12.

Fiala, N. (2015), "Economic Consequences of Forced Displacement", The Journal of Development Studies, 51(10), 1275-1293.

Hounkannounon, B. (2011), "Bootstrapping Differences-in-Differences Estimates", CIREQ, Universite de Montreal <https://www.rbnz.govt.nz//media/ReserveBank/Files/Publications/Seminars\%20and\%20workshops/feb2012/46822 49.pdf?la=en>, 10.09.2018.

Kondylis, F. (2008), “Agricultural Outputs and Conflict Displacement: Evidence from a Policy Intervention in Rwanda", Economic Development and Cultural Change, 57(1), 33-66.

Maystadt, J.F. \& P. Verwimp (2014), "Winners and Losers among a Refugee-Hosting Population”, Economic Development and Cultural Change, 62(4), 769-809.

ORSAM - Ortadoğu Stratejik Araştırmalar Merkezi \& TESEV - Türkiye Ekonomi ve Sosyal Araştırmalar Vakfi (2015), "Suriyeli Sığınmacıların Türkiye'ye Etkileri”, ORSAM Rapor No. 195, Ankara.

Ruiz, I. \& C. Vargas-Silva (2013), “The Economics of Forced Migration”, Journal of Development Studies, 49(6), 772-784.

Sarvimaki, M. \& R. Uusitalo \& M. Jantti (2009), “Long-Term Effects of Forced Migration”, Discussion Paper, No. 4003, IZA.

Whitaker, B.E. (2002), "Refugees in Western Tanzania: The Distribution of Burdens and Benefits among Local Hosts", Journal of Refugee Studies, 15(4), 339-358.

Xu, Y. (2017), "Generalized Synthetic Control Method: Casual Inference with Interactive Fixed Effects Models", Political Analysis, 25(1), 57-76.

Zetter, R. (2012), Guidelines for Assessing the Impacts and Costs of Forced Displacement, World Bank, Washington DC, United States. 


\section{APPENDIX}

\section{A 1: Temporary Accommodation Centres Hosting Syrian Forced Migrants in Turkey} $(05 / 01 / 2017)$

\begin{tabular}{|c|c|c|}
\hline Province & Temporary Accommodation Centre & Population (Syrian) \\
\hline \multirow{5}{*}{ HATAY } & Altınözü Container Camp & 4973 \\
\hline & Yayladağ1 1 Tent Camp & 2646 \\
\hline & Yayladağ 2 Container Camp & 3659 \\
\hline & Apaydin Container Camp & 5216 \\
\hline & Güveççi Tent Camp & 3002 \\
\hline \multirow{5}{*}{ GAZİANTEP } & İslahiye 1 Tent Camp & 7389 \\
\hline & İslahiye 2 Tent Camp & 10023 \\
\hline & Karkamış Tent Camp & 6682 \\
\hline & Nizip 1 Tent Camp & 10082 \\
\hline & Nizip 2 Tent Camp & 4521 \\
\hline \multirow{5}{*}{ ŞANLIURFA } & Ceylanpınar Tent Camp & 22192 \\
\hline & Akçakale Tent Camp & 31767 \\
\hline & Harran Container Camp & 14042 \\
\hline & Viranşehir Tent Camp & 15561 \\
\hline & Suruç Tent Camp & 31757 \\
\hline \multirow{2}{*}{ KİLİS } & Öncüpınar Container Camp & 15990 \\
\hline & Elbeyli Beşiriye Container Camp & 20986 \\
\hline MARDIN & Midyat Tent Camp & 3484 \\
\hline KAHRAMANMARAŞ & Merkez Container Camp & 18579 \\
\hline OSMANIYE & Cevdetiye Tent Camp & 7250 \\
\hline ADIYAMAN & Merkez Tent Camp & 9694 \\
\hline ADANA & Sarıçam Tent Camp & 341 \\
\hline MALATYA & Beydağ1 Container Camp & 10267 \\
\hline
\end{tabular}

Source: Republic of Turkey Prime Ministry Disaster and Emergency Management Authority.

\section{A2: Distribution of Syrian Refugees in the Scope of Temporary Protection by Province (05/01/2017)}

\begin{tabular}{|c|c|c|c|c|c|c|c|c|c|}
\hline Province No. & Province & Registered & Population & $\begin{array}{l}\text { Comparison } \\
\text { Percentage with } \\
\text { Province } \\
\text { Population }\end{array}$ & $\begin{array}{l}\text { Province } \\
\text { No. }\end{array}$ & Province & Registered & Population & \begin{tabular}{|l|} 
Comparison \\
Percentage with \\
Province \\
Population
\end{tabular} \\
\hline \multicolumn{2}{|l|}{ Total } & 2841036 & 78741053 & $\% 3,61$ & \multicolumn{2}{|l|}{ Total } & 2841036 & 78741053 & $\% 3,61$ \\
\hline 1 & Adana & 149668 & 2183167 & $\% 6,86$ & 42 & Kahramanmaraş & 87084 & 1096610 & $\% 7,94$ \\
\hline 2 & Adiyaman & 24876 & 602774 & $\% 4,13$ & 43 & Karabük & 379 & 236978 & $\% 0,16$ \\
\hline 3 & Afyon & 4218 & 709015 & $\% 0,59$ & 44 & Karaman & 516 & 242196 & $\% 0,21$ \\
\hline 4 & Ağr1 & 861 & 547210 & $\% 0,16$ & 45 & Kars & 159 & 292660 & $\% 0,05$ \\
\hline 5 & Aksaray & 1165 & 386514 & $\% 0,30$ & 46 & Kastamonu & 754 & 372633 & $\% 0,20$ \\
\hline 6 & Amasya & 217 & 322167 & $\% 0,07$ & 47 & Kayseri & 55497 & 1341056 & $\% 4,14$ \\
\hline 7 & Ankara & 67424 & 5270575 & $\% 1,28$ & 48 & Kırıkkale & 683 & 270271 & $\% 0,25$ \\
\hline 8 & Antalya & 368 & 2288456 & $\% 0,02$ & 49 & Kırklareli & 2086 & 346973 & $\% 0,60$ \\
\hline 9 & Ardahan & 80 & 99265 & $\% 0,08$ & 50 & Kırşehir & 692 & 225562 & $\% 0,31$ \\
\hline 10 & Artvin & 40 & 168370 & $\% 0,02$ & 51 & Kilis & 122539 & 130655 & $\% 93,79$ \\
\hline 11 & Aydın & 7459 & 1053506 & $\% 0,71$ & 52 & Kocaeli & 27575 & 1780055 & $\% 1,55$ \\
\hline 12 & Balıkesir & 1902 & 1186688 & $\% 0,16$ & 53 & Konya & 70379 & 2130544 & $\% 3,30$ \\
\hline 13 & Bartın & 31 & 190708 & $\% 0,02$ & 54 & Kütahya & 347 & 571463 & $\% 0,06$ \\
\hline 14 & Batman & 19425 & 566633 & $\% 3,43$ & 55 & Malatya & 20797 & 772904 & $\% 2,69$ \\
\hline 15 & Bayburt & 38 & 78550 & $\% 0,05$ & 56 & Manisa & 5912 & 1380366 & $\% 0,43$ \\
\hline 16 & Bilecik & 513 & 212361 & $\% 0,24$ & 57 & Mardin & 93480 & 796591 & $\% 11,74$ \\
\hline 17 & Bingöl & 716 & 267184 & $\% 0,27$ & 58 & Mersin & 140175 & 1745221 & $\% 8,03$ \\
\hline 18 & Bitlis & 668 & 340449 & $\% 0,20$ & 59 & Muğla & 8560 & 908877 & $\% 0,94$ \\
\hline 19 & Bolu & 1034 & 291095 & $\% 0,36$ & 60 & Muş & 838 & 408728 & $\% 0,21$ \\
\hline 20 & Burdur & 7831 & 258339 & $\% 3,03$ & 61 & Nevşehir & 5760 & 286767 & $\% 2,01$ \\
\hline 21 & Bursa & 103390 & 2842547 & $\% 3,64$ & 62 & Niğgde & 3255 & 346114 & $\% 0,94$ \\
\hline 22 & Çanakkale & 3432 & 513341 & $\% 0,67$ & 63 & Ordu & 621 & 728949 & $\% 0,09$ \\
\hline 23 & Çankırı & 340 & 180945 & $\% 0,19$ & 64 & Osmaniye & 41677 & 512873 & $\% 8,13$ \\
\hline 24 & Çorum & 1510 & 525180 & $\% 0,29$ & 65 & Rize & 630 & 328979 & $\% 0,19$ \\
\hline 25 & Denizli & 7362 & 993442 & $\% 0,74$ & 66 & Sakarya & 7072 & 953181 & $\% 0,74$ \\
\hline 26 & Diyarbakır & 29144 & 1654196 & $\% 1,76$ & 67 & Samsun & 4024 & 1279884 & $\% 0,31$ \\
\hline 27 & Düzce & 574 & 360388 & $\% 0,16$ & 68 & Siirt & 3178 & 320351 & $\% 0,99$ \\
\hline 28 & Edirne & 6490 & 402537 & $\% 0,16$ & 69 & Sinop & 71 & 204133 & $\% 0,03$ \\
\hline 29 & Elazı̆̆ & 5181 & 574304 & $\% 0,90$ & 70 & Sivas & 2190 & 618617 & $\% 0,35$ \\
\hline
\end{tabular}


Tunaer-Vural, B.M. (2020), "Impact of Syrian Forced Migration on Turkish Economy", Sosyoekonomi, Vol. 28(43), 49-64.

\begin{tabular}{|c|c|c|c|c|c|c|c|c|c|}
\hline 30 & Erzincan & 174 & 222918 & $\% 0,08$ & 71 & Şanlıurfa & 406212 & 1892320 & $\% 21,47$ \\
\hline 31 & Erzurum & 526 & 762321 & $\% 0,07$ & 72 & Şırnak & 14329 & 490184 & $\% 2,92$ \\
\hline 32 & Eskişehir & 2082 & 826716 & $\% 0,25$ & 73 & Tekirdağ & 5961 & 937710 & $\% 0,64$ \\
\hline 33 & Gaziantep & 317989 & 1931836 & $\% 16,46$ & 74 & Tokat & 811 & 593990 & $\% 0,14$ \\
\hline 34 & Giresun & 146 & 426686 & $\% 0,03$ & 75 & Trabzon & 2067 & 768417 & $\% 0,27$ \\
\hline 35 & Gümüşhane & 67 & 151449 & $\% 0,04$ & 76 & Tunceli & 90 & 80076 & $\% 0,10$ \\
\hline 36 & Hakkâri & 874 & 278775 & $\% 0,31$ & 77 & Uşak & 1203 & 353048 & $\% 0,34$ \\
\hline 37 & Hatay & 379264 & 1533507 & $\% 24,73$ & 78 & Van & 1645 & 1096397 & $\% 0,15$ \\
\hline 38 & Iğdır & 81 & 192435 & $\% 0,04$ & 79 & Yalova & 2707 & 233009 & $\% 1,16$ \\
\hline 39 & Isparta & 6193 & 421766 & $\% 1,47$ & 80 & Yozgat & 3027 & 419440 & $\% 0,72$ \\
\hline 40 & $\begin{array}{l}\text { İstanbul } \\
\end{array}$ & 442204 & 14657434 & $\% 3,02$ & 81 & Zonguldak & 303 & 595907 & $\% 0,05$ \\
\hline 41 & İzmir & 100194 & 4168415 & $\% 2,40$ & & & & & \\
\hline
\end{tabular}

Source: Republic of Turkey Ministry of Interior Directorate General of Migration Management, Migration Statistics.

\section{A3: Difference in Difference Estimates for Main Macroeconomic Variables}

\begin{tabular}{|c|c|c|c|c|c|}
\hline & \multicolumn{2}{|c|}{ 2006- 2011} & \multicolumn{2}{|c|}{$2012-2017$} & \multirow{2}{*}{ DD } \\
\hline TR10: İstanbul & TR10 & TR & TR10 & TR & \\
\hline Unemployment (\%) & 12,50 & 7,74 & 10,43 & 6,95 & $-1,28$ \\
\hline Inflation (\%) & 7,32 & 8,13 & 7,86 & 7,85 & 0,74 \\
\hline Inflation: Food (\%) & 8,37 & 8,54 & 11,02 & 10,89 & 0,30 \\
\hline Inflation: Housing (\%) & 6,30 & 9,34 & 8,41 & 7,09 & 4,36 \\
\hline \multirow[t]{2}{*}{ Production (per capita / TL) } & 30685 & 14090 & 43580 & 21435 & 5550 \\
\hline & \multicolumn{2}{|c|}{$2006-2011$} & \multicolumn{2}{|c|}{$2012-2017$} & \multirow{2}{*}{ DD } \\
\hline TR31: İzmir & TR31 & TR & TR31 & TR & \\
\hline Unemployment (\%) & 14,87 & 7,74 & 14,35 & 6,95 & 0,27 \\
\hline Inflation $(\%)$ & 7,81 & 8,13 & 8,23 & 7,85 & 0,70 \\
\hline Inflation: Food (\%) & 8,55 & 8,54 & 11,92 & 10,89 & 1,36 \\
\hline Inflation: Housing (\%) & 8,63 & 9,34 & 7,12 & 7,09 & 0,82 \\
\hline \multirow[t]{2}{*}{ Production (per capita / TL) } & 21624 & 14090 & 31260 & 21435 & 2291 \\
\hline & \multicolumn{2}{|c|}{$2006-2011$} & \multicolumn{2}{|c|}{$2012-2017$} & \multirow{2}{*}{ DD } \\
\hline TR51: Ankara & TR51 & TR & TR51 & TR & \\
\hline Unemployment (\%) & 11,73 & 7,74 & 11,15 & 6,95 & 0,11 \\
\hline Inflation $(\%)$ & 7,63 & 8,13 & 7,68 & 7,85 & 0,33 \\
\hline Inflation: Food (\%) & 9,46 & 8,54 & 11,43 & 10,89 & $-0,44$ \\
\hline Inflation: Housing (\%) & 6,07 & 9,34 & 8,15 & 7,09 & 4,33 \\
\hline \multirow[t]{2}{*}{ Production (per capita / TL) } & 26993 & 14090 & 36830 & 21435 & 2492 \\
\hline & \multicolumn{2}{|c|}{ 2006- 2011} & \multicolumn{2}{|c|}{$2012-2017$} & \multirow{2}{*}{$\mathrm{DD}$} \\
\hline TR41: Bursa & TR41 & TR & TR41 & TR & \\
\hline Unemployment (\%) & 8,13 & 7,74 & 6,84 & 6,95 & $-0,50$ \\
\hline Inflation (\%) & 7,54 & 8,13 & 7,98 & 7,85 & 0,72 \\
\hline Inflation: Food (\%) & 8,19 & 8,54 & 11,04 & 10,89 & 0,50 \\
\hline Inflation: Housing $(\%)$ & 7,38 & 9,34 & 7,10 & 7,09 & 1,97 \\
\hline \multirow[t]{2}{*}{ Production (per capita / TL) } & 20528 & 14090 & 29139 & 21435 & 1266 \\
\hline & \multicolumn{2}{|c|}{ 2006- 2011} & \multicolumn{2}{|c|}{ 2012-2017 } & \multirow{2}{*}{ DD } \\
\hline TR42: Kocaeli & TR42 & TR & TR42 & TR & \\
\hline Unemployment (\%) & 11,50 & 7,74 & 9,86 & 6,95 & $-0,85$ \\
\hline Inflation $(\%)$ & 7,52 & 8,13 & 7,48 & 7,85 & 0,24 \\
\hline Inflation: Food (\%) & 7,28 & 8,54 & 10,98 & 10,89 & 1,35 \\
\hline Inflation: Housing (\%) & 8,09 & 9,34 & 6,35 & 7,09 & 0,51 \\
\hline \multirow[t]{2}{*}{ Production (per capita / TL) } & 19296 & 14090 & 30290 & 21435 & 3649 \\
\hline & \multicolumn{2}{|c|}{ 2006- 2011} & \multicolumn{2}{|c|}{$2012-2017$} & \\
\hline TR52: Konya & TR52 & TR & TR52 & TR & DD \\
\hline Unemployment (\%) & 6,77 & 7,74 & 5,24 & 6,95 & $-0,74$ \\
\hline Inflation $(\%)$ & 8,06 & 8,13 & 8,03 & 7,85 & 0,25 \\
\hline Inflation: Food (\%) & 9,75 & 8,54 & 10,98 & 10,89 & $-1,12$ \\
\hline Inflation: Housing (\%) & 8,64 & 9,34 & 6,94 & 7,09 & 0,55 \\
\hline Production (per capita / TL) & 13831 & 14090 & 22356 & 21435 & 1180 \\
\hline & & & & & \\
\hline TR62: Adana & TR62 & TR & TR62 & TR & DD \\
\hline Unemployment (\%) & 12,57 & 8,76 & 11,46 & 6,95 & 0,70 \\
\hline Inflation (\%) & 8,05 & 8,13 & 8,42 & 7,85 & 0,65 \\
\hline Inflation: Food (\%) & 9,55 & 8,54 & 9,58 & 10,89 & $-2,32$ \\
\hline Inflation: Housing (\%) & 8,41 & 9,34 & 7,24 & 7,09 & 1,08 \\
\hline Production (per capita / TL) & 14131 & 14090 & 20316 & 21435 & -1160 \\
\hline
\end{tabular}


Tunaer-Vural, B.M. (2020), "Impact of Syrian Forced Migration

on Turkish Economy", Sosyoekonomi, Vol. 28(43), 49-64.

\begin{tabular}{|c|c|c|c|c|c|}
\hline & \multicolumn{2}{|c|}{ 2006- 2011} & \multicolumn{2}{|c|}{$2012-2017$} & \multirow{2}{*}{ DD } \\
\hline TR63: Hatay & TR63 & TR & TR63 & TR & \\
\hline Unemployment (\%) & 12,07 & 8,76 & 13,78 & 6,95 & 3,52 \\
\hline Inflation $(\%)$ & 7,97 & 8,13 & 8,11 & 7,85 & 0,42 \\
\hline Inflation: Food (\%) & 8,66 & 8,54 & 9,94 & 10,89 & $-1,07$ \\
\hline Inflation: Housing (\%) & 10,23 & 9,34 & 7,08 & 7,09 & $-0,90$ \\
\hline \multirow[t]{2}{*}{ Production (per capita / TL) } & 11528 & 14090 & 16115 & 21435 & -2758 \\
\hline & \multicolumn{2}{|c|}{ 2006- 2011} & \multicolumn{2}{|c|}{ 2012-2017 } & \multirow{2}{*}{ DD } \\
\hline TR71: Kayseri & TR71 & TR & TR71 & TR & \\
\hline Unemployment (\%) & 10,5 & 8,76 & 9,75 & 6,95 & 1,06 \\
\hline Inflation (\%) & 9,20 & 8,13 & 7,98 & 7,85 & $-0,94$ \\
\hline Inflation: Food (\%) & 9,80 & 8,54 & 11,35 & 10,89 & $-0,80$ \\
\hline Inflation: Housing (\%) & 8,64 & 9,34 & 7,06 & 7,09 & 0,67 \\
\hline \multirow{2}{*}{ Production (per capita / TL) } & 14320 & 14090 & 21990 & 21435 & 325 \\
\hline & \multicolumn{2}{|c|}{$2006-2011$} & \multicolumn{2}{|c|}{ 2012-2017 } & \multirow{2}{*}{ DD } \\
\hline TRB1: Malatya & TRB1 & TR & TRB1 & TR & \\
\hline Unemployment (\%) & 9,67 & 8,76 & 7,21 & 6,95 & $-0,65$ \\
\hline Inflation (\%) & 8,38 & 8,13 & 7,13 & 7,85 & $-0,97$ \\
\hline Inflation: Food (\%) & 8,55 & 8,54 & 10,10 & 10,89 & $-0,80$ \\
\hline Inflation: Housing $(\%)$ & 10,25 & 9,34 & 6,60 & 7,09 & $-1,40$ \\
\hline \multirow[t]{2}{*}{ Production (per capita / TL) } & 11,258 & 14090 & 16215 & 21435 & -2388 \\
\hline & \multicolumn{2}{|c|}{ 2006- 2011} & \multicolumn{2}{|c|}{$2012-2017$} & \multirow{2}{*}{ DD } \\
\hline TRC1: Gaziantep & TRC1 & TR & TRC1 & TR & \\
\hline Unemployment (\%) & 12,7 & 8,76 & 8,11 & 6,95 & $-2,78$ \\
\hline Inflation $(\%)$ & 8,25 & 8,13 & 9,10 & 7,85 & 1,13 \\
\hline Inflation: Food (\%) & 9,01 & 8,54 & 11,13 & 10,89 & $-0,23$ \\
\hline Inflation: Housing (\%) & 9,89 & 9,34 & 9,12 & 7,09 & 1,48 \\
\hline \multirow[t]{2}{*}{ Production (per capita / TL) } & 10880 & 14090 & 18368 & 21435 & 143 \\
\hline & \multicolumn{2}{|c|}{ 2006- 2011} & \multicolumn{2}{|c|}{ 2012-2017 } & \multirow[b]{2}{*}{ DD } \\
\hline TRC2: Şanlıurfa & TRC2 & TR & TRC2 & TR & \\
\hline Unemployment $(\%)$ & 9,37 & 8,76 & 16,38 & 6,95 & 8,82 \\
\hline Inflation $(\%)$ & 8,29 & 8,77 & 8,85 & 7,85 & 1,48 \\
\hline Inflation: Food (\%) & 7,68 & 8,54 & 11,25 & 10,89 & 1,22 \\
\hline Inflation: Housing (\%) & 10,99 & 9,34 & 9,24 & 7,09 & 0,50 \\
\hline \multirow[t]{2}{*}{ Production (per capita / TL) } & 8014 & 14090 & 11255 & 21435 & -4104 \\
\hline & \multicolumn{2}{|c|}{ 2006- 2011} & \multicolumn{2}{|c|}{$2012-2017$} & \multirow[b]{2}{*}{ DD } \\
\hline TRC3: Mardin & TRC3 & TR & TRC3 & TR & \\
\hline Unemployment (\%) & 15,00 & 8,76 & 21,4 & 6,95 & 8,21 \\
\hline Inflation (\%) & 7,44 & 8,77 & 7,25 & 7,85 & 0,73 \\
\hline Inflation: Food (\%) & 7,11 & 8,54 & 10,30 & 10,89 & 0,84 \\
\hline Inflation: Housing (\%) & 10,06 & 9,34 & 7,05 & 7,09 & $-0,76$ \\
\hline Production (per capita / TL) & 8816 & 14090 & 13500 & 21435 & -2661 \\
\hline
\end{tabular}

